\title{
TELEFONIVESTLUSED EESTI KEELE KUI TEISE KEELE ÕPIKUTES: FUNKTSIOONID JA SISSEJUHATUSTE STRUKTUUR
}

\section{Raili Pool, Andriela Rääbis}

\begin{abstract}
Ülevaade. Artikkel käsitleb täiskasvanud algajatele mõeldud eesti keele kui teise keele õpikutes sisalduvate telefonivestluste funktsioone ja struktuuri, keskendudes vestluste sissejuhatusele. Uurimisaineseks on aastatel 1999-2009 ilmunud eesti keele kui teise keele kuues õpikus leiduvad 56 telefonidialoogi, võrdlusmaterjaliks 131 argi- ja 577 institutsionaalset telefonikõnet Tartu Ülikooli eesti suulise keele korpusest. Kahe materjalikogu võrdluse põhjal saab väita, et lisaks kutsungi puudumisele eristab õpikudialooge korpusedialoogidest eelkõige vastaja esimese vooru sagedane puudumine, seda eriti argivestlustes. Samuti pole argiste õpikunäidete puhul tihti selge, kuidas osalejad teineteise identifitseerimiseni jõuavad. Institutsionaalsed õpikudialoogid vastavad enamasti reaalsetele suhtlussituatsioonidele. Selgelt tuleb esile õpikudialoogide metoodiline eesmärk - pakkuda õppijatele vajalikke keelelisi vahendeid suhtlusprobleemide lahendamiseks. Seejuures on telefonivestlustel lisaks pragmaatilisele funktsioonile sageli äratuntavalt ka mõne grammatika- või sõnavarateema õpetamise funktsioon.*
\end{abstract}

Võtmesõnad: teise keele õpetamine, vestlusanalüüs, telefonivestluste sissejuhatus, autentsus, eesti keel

\section{Sissejuhatus}

Artiklis käsitleme eesti keele kui teise keele õpikutes sisalduvate telefonivestluste funktsioone ja sissejuhatuste struktuuri ning võrdleme õpikudialoogide ülesehitust autentsete suuliste telefonidialoogidega. Autentsete vestluste uurimismeetodina kasutame vestlusanalüüsi. Eri kultuurides on telefonivestluste sissejuhatuse mudelid erinevad, sissejuhatuse sekventsid esinevad eri tingimustel ning neid ei

* Artikli valmimist on toetanud Euroopa Regionaalarengute Fond Eesti Arvutiteaduse Tippkeskuse kaudu, Eesti Teadusfondi grandid 7492, 7503 ja 8558, Haridus- ja Teadusministeeriumi sihtfinantseeritav teema SF0180078s08 "Loomulike keelte arvutitöötluse formalismide ja efektiivsete algoritmide väljatöötamine ning eesti keelele rakendamine" ja riiklik programm "Eesti keele keeletehnoloogiline tugi" ning Tartu Ülikooli rahvusteaduste baasfinantseerimise raames toetatav projekt "Eesti keel loomulikus suhtluses". 
saa lihtsalt teise kultuuri üle kanda. Kui inimene käitub teise keele ning kultuuri keskkonnas oma kultuuri mudeli järgi, võivad tekkida probleemid. Seetõttu on oluline tutvustada eesti keelt võõrkeelena õppijatele eestlaste tüüpilist vestluskäitumist ning valmistada neid ette reaalseteks suhtlusolukordadeks eestikeelses keskkonnas. Õppijad soovivad enamasti kasutada õpitavat keelt ka väljaspool klassiruumi ning peaksid sihtkeeles suhtlemiseks tarvilikud sotsiopragmaatilised teadmised saama keeleõppe käigus ning õppematerjalide toel. Keeleõpikutes esitatavatel telefonidialoogidel on seejuures täita oluline roll, kuna õpik on õppijale autoriteet ning õppijad püüavad õpikudialoogide keelemudeleid kõnelemisel järele aimata. Kui oppikutekstid esindavad loomulikku keelekasutust, on õppijatel lihtsam õpitava keele keskkonnas toime tulla ning arusaamatusi tekib vähem.

Artikli eesmärgiks on tutvustada õpikutes sisalduvate telefonidialoogide funktsioone ja tüüpe ning selgitada välja õpikudialoogide sissejuhatuste struktuuri autentsus. Selleks kirjeldatakse esmalt eesti suulise keele korpuse telefonidialoogide sissejuhatuste ülesehitust. Seejärel vaadeldakse, kuivõrd õpikuvestlused sarnanevad autentsete dialoogidega ning millised on peamised erinevused, millele õpikukirjutajad võiksid ehk tulevikus tähelepanu pöörata, kui soovitakse õpikutekstide autentsust suurendada.

\section{Uurimismaterjal}

Analüüsitav materjalikogu koosneb 56 dialoogist, mis on pärit kuuest aastatel 1999-2009 ilmunud täiskasvanud algajatele mõeldud eesti keele õpikust (Pajusalu jt 1999, Pesti, Ahi 1999, Leemets 2002, Kitsnik, Kingisepp 2008, Mangus, Simmul 2009, Tomingas 2009). Võrdlusmaterjaliks on 131 argitelefonikõnet ja 577 institutsionaalset telefonikõnet Tartu Ülikooli eesti suulise keele korpusest (korpuse kohta vt Hennoste 2000, 2003). Võrdluskorpust kogudes on silmas peetud, et suhtlus oleks loomulik. Valdavalt on tegu lauatelefonikõnedega. Mobiiltelefonil vastatakse 9 argivestluses ja 4 institutsionaalses dialoogis; helistaja kasutab mobiiltelefoni 13 argivestluses, institutsionaalsete telefonikõnede puhul ei ole sageli teada, kas helistatakse lauatelefonilt või mobiililt. Argivestlustes suhtlevad pereliikmed, sõbrad, sugulased või tuttavad. Institutsionaalsetes telefonikõnedes on helistajaks klient ja vastajaks ametiisik. Situatsioonidest on kesksed helistamine infotelefonile, polikliiniku registratuuri, reisibüroosse, bussijaama, takso tellimine. Neis dialoogides on osalejad enamasti võõrad, vaid 13 dialoogis tuttavad (nt polikliiniku arst või õde helistab registratuuri). Tekstide litereerimisel on kasutatud Gail Jeffersoni transkriptsioonisüsteemi eesti keelele kohandatud varianti (vt Hennoste 2000).

Telefonidialooge on täiskasvanud algajatele mõeldud eesti keele õpikutes suhteliselt palju, mis näitab, et telefonivestluste konventsioonide ópetamist mitte-eestlastele peetakse oluliseks. Võrdluseks on võimalik välja tuua andmed Jean Wongi (2002) uurimusest, milles ta kõrvutab kaheksas inglise keele õpikus leidunud 30 telefonidialoogi Emanuel A. Schegloffi Ameerika telefonivestluse sissejuhatuse mudeliga (Schegloff 1986: 117-118) ning väidab, et oli raske leida inglise keele õpikuid, milles telefonivestlusi oleks kasutatud. Eesti keele õpikutes on telefonidialoogid tavaline tekstiliik, mis kuulub just algajatele mõeldud õppekirjandusse, edasijõudnutele suunatud õpikutes telefonivestlusi üldiselt enam ei kasutata. 


\section{Telefonivestluste uurimisest}

Vestlusanalüüs võimaldab uurida inimestevahelist suhtlust mikrotasandil (Sacks 1992 [1964-1972], Sacks jt 1974, Schegloff 2007). Mikroanalüüs on vahend, mis aitab tuvastada suhtluses läbiviidavaid sotsiaalseid tegevusi. Vestlusanalüüsi kohaselt reguleerivad vestlust vooruvahetussüsteem (ingl turn-taking organization), järjendiliigendus (sequence organization), parandusmehhanism (repair organization) ja suhtlustegevuse moodustusviis (action formation). Lähtutakse sellest, et igasugune vestlus on üles ehitatud järjendite ehk sekventsidena: iga voor on seotud eelneva vooruga ja loob omakorda konteksti järgneva vooru jaoks. Omavahel eriti tugevalt seotud kahe vooru kogumeid, milles esiliige loob kindlat tüüpi järelliikme ootuse, nimetatakse naabruspaarideks (Schegloff, Sacks 1973: 295-296).

Vestlusanalüüsi meetodil on telefonivestlusi uuritud juba alates 1960. aastatest. Enamik uurijaid on keskendunud vestluse sissejuhatusele. Teerajajaks oli Schegloff, kes on käsitlenud Põhja-Ameerika ingliskeelseid telefonivestlusi ning esitanud kõige tuntuma sissejuhatuse mudeli, mis koosneb neljast tuumsekventsist:

1) Kutsung - vastus: telefonihelin ja vastaja esimene voor.

2) Identifitseerimine (ja/või äratundmine): osalejad tutvustavad ennast ja väljendavad partneri äratundmist.

3) Tervitused.

4) How-are-you (kuidas-läheb)-sekventsid. (Schegloff 1986: 117-118)

Pärast nende etappide läbimist jõuavad vestlejad positsioonile, kus vestlusse saab tuua esimese teema. Schegloff (1986: 116) nimetab seda ankrupositsiooniks. Esimest teemat alustab tavaliselt helistaja.

Tuumsekventsid ei moodusta automaatselt toimivat süsteemi. Tegelikus suhtluses kaldutakse sageli sellest mudelist kõrvale. Schegloffi mudel aitab aga kirjeldada kõiki sissejuhatusi: ta liigendab ja järjestab telefonivestluse alustamiseks vajalikud tegevused.

Alates 1980. aastate lõpust on telefonivestluse alustamist uuritud paljudes keeltes ja kultuurides. Enamik varasemaid uurimusi käsitleb Euroopa kultuure, telefonisuhtlus muudes kultuurides (nt Hiina, Korea, Ladina-Ameerika, Iraan, Venemaa, Jaapan) on tõusnud huviorbiiti alles viimase kümne aasta jooksul. On püütud leida vastust küsimusele, kas telefonisuhtlus toimub erinevates ühiskondades samadel ülesehituse printsiipidel või varieerub kultuuriti. Eri kultuuride telefonivestluste sissejuhatusi käsitledes on neid enamasti võrreldud Schegloffi mudeliga, püüdes leida sarnasusi ja erinevusi. Tuumsekventsid esinevad küll kõikides uuritud kultuurides, kuid enamik autoreid toob välja mingeid erinevusi Schegloffi mudelist, nt sekventside teistsugune järjestus (Coronel-Molina 1998, Sifianou 2002, Sun 2004, Lee 2006), kuidas-läheb-sekventsi vähesus (Hakulinen 1992, Lindström 1994, Pavlidou 1994) või laiendamine (Coronel-Molina 1998, Taleghani-Nikazm 2002), tervituste ärajätmine (Sifianou 2002, Lee 2006), kutsungi verbaalne kordamine (Lee 2006) jm.

Enamik uurimusi käsitleb lauatelefonikõnesid. Mobiilikõnede sissejuhatusi on uuritud alles üsna vähe (nt Arminen 2005, 2006, Hutchby, Barnett 2005, Arminen, Leinonen 2006). On leitud, et mobiilisuhtlus järgib paljusid lauatelefonisuhtluse norme, kuid samal ajal erinevad need telefonikõnede tüübid üksteisest 
süstemaatiliselt. Olulisimad erinevused on tutvustamise ärajätmine ning partneri asukoha küsimine.

\section{Eesti keele kui teise keele õpikutes sisalduvate telefonivestluste funktsioonid}

Õpikudialoogidel on traditsiooniliselt nii pragmaatilisi kui ka keele struktuuri õpetamisega seotud ülesandeid, sama käib ka telefonivestluste kohta. Eriti algtaseme keeleõppe puhul võimaldab dialoogilise teksti kasutamine õppematerjalis edasi anda kinnisväljenditena esinevaid suhtlusvormeleid, mida õppijad veel detailselt analüüsida ei oska ja mis õpitakse ära tervikfraasidena, kasutamiseks teatud suhtlusolukorras (Tanner 2008: 166) (nt tänan küsimast, pole viga jne). Telefonivestluste funktsioonid võib jagada kaheks:

1) pragmaatilise info vahendamine, eestikeelsetele telefonikõnedele omaste suhtluskonventsioonide tutvustamine;

2) keele struktuuri õpetamine (grammatiliste ja leksikaalsete vahendite tutvustamine dialoogi kaudu).

Võib eeldada, et kõigi telefonidialoogide üks eesmärk on pragmaatilise info vahendamine, millega kaasneb erineva grammatilise ning sõnavaralise materjali edastamine. Kui nende üheks eesmärgiks ei oleks püüda sissejuhatavate sekventsidega luua pilti tegelikust telefonivestlusest, poleks olnud põhjust kasutada just telefonivestlust, vaid võinuks valida mõne muu tekstiliigi. Analüüsitud 56 telefonivestluse hulgas oli selliseid, mille puhul domineeris pragmaatiline funktsioon - dialoogi ülesandeks ongi pakkuda just telefonikõnedes tüüpiliselt kasutatavaid vormeleid ja tutvustada reaalseid suhtlussituatsioone. Näide (1) illustreerib tüüpilisi infotelefonile tehtavaid kõnesid.

(1) - Infotelefon kuuleb. Tere õhtust!

- Tere! Ma palun "Vanalinna" hotelli telefoni.

- Üks hetk, palun! Vastuvõtu telefon on 678224.

- Tänan väga! (Pesti, Ahi 1999: 132)

Sageli on õpikudialoogides selgelt näha keele struktuuri õpetamise funktsioon. Näites (2) on telefonivestluse žanr valitud kaassõnaühendite tutvustamiseks ning eelviimase vooru pikkus tuleneb grammatika tutvustamise funktsiooni domineerimisest.

(2) Telefon heliseb.

- Halloo, Miisu kuuleb!

- Tere, Miisu! Tule meie õue minuga mängima!

- Ma ei saa praegu tulla.

- Ei saa? Miks sa ei saa?

- Mul ei ole aega.

- Ei ole aega? Mida sa siis teed?

- Ma koristan tuba. Maiel on kõik nii segamini. Tema lõngakerad olid korvi sees põranda peal. Ma võtsin punase lõngakera ja veeretasin selle põranda 
keskele. Siis põimisin ma lõnga ümber laua. Sinise kera veeretasin ma akna alla ja tõmbasin lõnga akna juurest ukse juurde. Kollane kera oli voodi kohal riiuli peal. Nüüd on ta kapi taga. Kogu põrand on nüüd nagu ilus kirju vaip. Küll Maie rõõmustab, kui koju tuleb!

- Arvad sa nii? Ma arvan, et sa saad hoopis kere peale!

(Leemets 2002: 297)

Grammatikast lähtuv õpikudialoogide koostamisprintsiip on lisaks eesti keelele levinud ka teiste keelte puhul, nt soome (vt Tanner 2008) ja inglise keele õpikutes (vt Carter 1998). Lisaks eesti keele grammatilise ehituse tutvustamisele on telefonidialoogidel sageli ka mõne kindla sõnavarateema illustreerimise funktsioon. Näiteks tutvustatakse vanaema ja lapselapse vahelise telefonivestlusega pealkirja all “Mida ma poest toon?" tavalisemate toiduainete nimetusi ning ühtlasi ka sõnade partitiivivormi (nt Võta kaks leiba ja kolm saia, Too natuke sinki ja juustu jne) (Tomingas 2009: 222). Korteriomaniku ja korteri üürimisest huvitatud isiku vahelise telefonikõne abil saab õpetada üürimise ja mööbliga seotud sõnavara (nt Kas teil on korter üürile anda?, Seal on mõned mööbliesemed: kušett, laud, paar tooli jne) (Pesti, Ahi 1999: 151). Bussijaama infotelefonil helistamist illustreeriv dialoog sisaldab tarvilikke sõnu ja väljendeid, mida õppijatel ka tegelikus elus bussipileti ostmisel kindlasti vaja läheb (nt Kas üliõpilastele soodustusi on?, Rahvusvahelise üliõpilaspiletiga saab 20\% hinnaalandust jne) (Pajusalu jt 1999: 126). Seejuures on õpikukirjutajad rakendanud telefonidialooge ka erinevate osaoskuste õpetamise teenistusse - telefonivestlused pole pelgalt lugemiseks, vaid neid kasutatakse ka kuulamisülesannetena (nt Kitsnik, Kingisepp 2008). Õpikudialoogide tegelik kasutamine oleneb siiski suuresti ka õpetajast ning sellest, kuidas ta õpikut tunnis kasutab ja tekste interpreteerib. Praegusel kommunikatiivse keeleõpetuse ajastul on õpikute telefonidialoogid kindlasti baasiks rollimängudele, milles õppijad rakendavad õpikuvestlustes sisaldunud vormeleid ning toetuvad ka vestluste ülesehitusele.

\section{Telefonivestluste tüübid}

Telefonikõnesid saab liigitada mitmelt aluselt: lähtudes suhtluse argisusest või ametlikkusest, suhtluse põhieesmärgist, telefoni tüübist, osalejate rollidest (Rääbis 2009: 29). Vaadeldavad õpikudialoogid jagunevad järgmiselt: argivestlusi on 30, institutsionaalseid dialooge 17, määratlematut tüüpi dialooge 9.

Vastavalt suhtluse põhieesmärgile jagunevad vestlused kahte rühma: kindla eesmärgiga suhtlemine (vahetatakse infot või täidetakse mingi ülesanne) ja suhtluses osalemine (primaarsed on interpersonaalsed motiivid) (vt Hennoste 2003: 492). Andriela Rääbis (2009) on nimetanud esimest tüüpi vestlusi infovestlusteks ja teist tüüpi suhtehoidmisvestlusteks. Institutsionaalsed telefonikõned on infovestlused. Argikõnesid on mõlemat tüüpi: infovestluses soovitakse näiteks midagi küsida, kokku leppida, esitada kutse jms, suhtehoidmisvestluse puhul pole muud helistamise põhjust kui sotsiaalseid suhteid hoida, igapäevastest asjadest lobiseda. Argistes õpikudialoogides on helistaja eesmärk enamasti kutse esitamine või kokkusaamise kavandamine. Suhtehoidmisvestluse näiteid vaadeldavates õpikutes ei ole. 
Lauatelefonikõned ja mobiilikõned ei ole eesti keele õpikutes selgelt eristatud. Vestluse sisust võib mõnel juhul oletada, et helistatakse mobiilile, kuid sellele eraldi tähelepanu ei pöörata.

Osalejate rollidest lähtudes jagunevad vaadeldavad vestlused kaheks: helistaja räg̈gib kas adressaadiga (inimesega, kellega ta vestelda soovib) või vahendajaga, kes vastab telefonile ning annab toru adressaadile üle või teatab, et viimast ei ole kohal. Vahendajaga vestlemise näiteid on nii koju kui ametiasutusse helistamise puhul, kokku 14 näidet. Lisaks sellele on esitatud kuus valeühenduse näidet. Vahendajaga vestlemise ning valeühenduse näidete hulk materjali hulgas on suhteliselt suur. See annab tunnistust õpikukirjutajate eesmärgist valmistada õppijaid ette probleemseteks suhtlussituatsioonideks.

\section{6. Õpikutes sisalduvate telefonivestluste sissejuhatuste struktuuri autentsus}

Järgnevalt vaatleme, kuivõrd vastab õpikuvestluste sissejuhatuste struktuur autentsete telefonivestluste sissejuhatuste ülesehitusele. Teise keele õppematerjalide koostamisel on autentsetel tekstidel oluline roll, kuna need esindavad loomulikku keelt, millega õppijad ka väljaspool keeletundi kokku puutuvad. Seejuures on autentsuse mõistet võimalik käsitleda mitmeti. Traditsiooniliselt mõeldakse autentsete tekstide all selliseid tekste, mis on algselt loodud mõneks muuks, mitte keeleõppe otstarbeks, nt ajaleheartiklid, tooteinfo, kuulutused jne (Crossley jt 2007: 17) ning oskuslik lihtsustamine ei vähenda autentsust (Guariento, Morley 2001: 348). Lisaks sellele võib autentsetena käsitada ka mingi õpperühma jaoks spetsiaalselt väljavalitud tekste ning tekste, mis on koostatud keeleõppe otstarbel ja meenutavad mingit autentset teksti, nt elektronkirja vm (Nissilä jt 2006: 153-154). Autentseid tekste ei peaks automaatselt õpikutekstidest või spetsiaalselt õppijarühmale (nt lastele) suunatud tekstidest paremaks pidama, vaid tekstide hindamisel tuleks rohkem keskenduda sellele, kuidas need õpetussituatsioonis töötavad ning kas nendega saab siduda autentset tegevust (van Lier 1996: 136-137).

Senised teisi keeli puudutavad uurimused on näidanud märgatavaid erinevusi teise keele õpikutes sisalduvate dialoogide ja loomulike suuliste vestluste struktuuris ja pragmaatikas. Näiteks on leitud, et inglise keele õpikudialoogid ei kajasta autentset interaktsiooni (Gilmore 2004) ning inglise keele õpikutes sisalduvate telefonivestluste sissejuhatused ei ole autentse sekventsistruktuuriga (Wong 2002). Soome ja saksa keele õpikute institutsionaalsed telefonidialoogid sisaldavad ebaloomulikke konstruktsioone ning erinevad vastavatest autentsetest vestlustest ka voorupikkuste ja suhtluskonventsioonide rakendamise poolest (Liefländer-Koistinen, Neuendorff 1989). Hispaania keele õppematerjalide ja autentsete telefonivestluste (restoranikohtade broneerimise kõned) võrdlus on näidanud, et õpikudialoogide grammatikast lähtuv koostamispõhimõte toob kaasa psühholingvistilise autentsuse ja suulise diskursuse erijoonte nappuse (Granena 2008). Eestikeelsete õpikudialoogide ja autentsete vestluste võrdlusel põhinevad uurimused seni puuduvad.

Siinses artiklis käsitletavad telefonidialoogid on õpikukirjutajate poolt konstrueeritud ning autentsusena saab niisugusel juhul käsitleda seda, kuivõrd õpikudialoogide sissejuhatuse sekventside ülesehitus vastab suulise korpuse loomulike 
vestluste vastavate sekventside ülesehitusele. Kuna artikkel keskendub telefonivestluste sekventsistruktuurile, ei vaadelda siin erinevusi õpiku- ja korpusedialoogide sõnavaras või grammatikas.

\subsection{Autentsete telefonivestluste sissejuhatus}

Eesti argitelefonivestluste sissejuhatusi on uurinud Rääbis (2009), kelle andmete kohaselt koosneb sissejuhatuse täismudel neljast sekventsist:

1) Kontakti loomine (kutsung - vastus).

2) Tervitamine.

3) Identifitseerimine.

4) Olukorra selgitamine.

Eesti telefonivestluste sissejuhatuse täismudel koosneb samadest sekventsidest kui Schegloffi mudel, kuid osade järjekord on teistsugune (tervitatakse enne tutvustamist) ning küsimusi partneri olukorra kohta esitatakse harva.

Sekventside järjestikuse asetusega täismudel on eesti telefonivestlustes aga üsna haruldane. Tavaliselt on sissejuhatused lühemad: mõni sekvents jäetakse ära või põimitakse mitme sekventsi osad ühte vooru.

Telefonikõne algab alati kontaktiloomissekventsiga. See on sissejuhatuse kõige rutiinsem sekvents, mille funktsiooniks on suhtluskanali avamine ja suhtlemisvalmiduse osutamine.

Teise sekventsi moodustavad tervitused. Analüüsitud argikõnede korpuses olid umbes pooltes vestlustes tervitused vastastikused, veerandis korpuses tervitas ainult helistaja, veerandis korpuses ei tervitatud.

Sissejuhatuse kolmas sekvents on identifitseerimine. See on sissejuhatuse kõige keerukam osa, mis koosneb mitmest tegevusest: osalejad tutvustavad ennast ja kinnitavad partneri äratundmist. Vestluses võidakse läbi viia kõik need tegevused, osa neist või kogu sekvents vahele jätta, kui partner muude sekventside käigus ära tuntakse. Vastastikune identifitseerimine on argivestluse jätkumise eeltingimuseks: kui partnerit ära ei tunta, tuleb tekkinud probleem kõigepealt lahendada. Eestis eelistavad nii vastajad kui ka helistajad olla hääle järgi ära tuntud. Tutvustamine või mittetutvustamine sõltub osalejate suhetest, kontaktide sagedusest, telefoni tüübist, vähemal määral ka helistamise põhjusest.

Selgitussekventsi all mõeldakse küsimusi ja kommentaare, mida esitatakse enne vestluse põhiosa juurde minekut. Eristuvad järgmised kategooriad:

1) küsimused ja kommentaarid partneri kohta (orienteeritud tema üldisele käekäigule, nt kuidas läheb, või konkreetsele tegevusele või olukorrale, nt mis teed; magasid vä; üksi oled);

2) kommentaarid enda kohta (nt mul on hääl ära);

3) kommentaarid helistamise kohta (nt ma mõtlesin, et elistan teile sinna);

4) küsimused ja kommentaarid kuuldavuse kohta (nt kuuled sa mind).

Selgitussekventsi kasutamise põhimõtted erinevad teistest sekventsidest. See on harv ja lisatakse vaid kindlatel tingimustel (Rääbis 2009: 158-159).

Näites (3) on tegemist argivestlusega. Katrina ja Laura on 35-aastased sõbrannad, kes ei suhtle omavahel kuigi sageli. Vestlus algab kutsung-vastus-sekventsiga, 
vastaja ütleb oma eesnime. Seejärel helistaja tervitab ja tutvustab ennast. Katrina ei vasta tervitusele, vaid reageerib tõusva intonatsiooniga partikliga noo?, mis annab vooru helistajale tagasi ja osutab soovile helistamise põhjuse juurde minna. Laura esitab aga küsimuse kuule, (.) 'on sul natukene `aega minuga ‘rääkida. See küsimus näitab partneriga arvestamist (koogiretsepti andmine võtab aega), aga võib osutada ka suhteprobleemile: suhted ei ole nii lähedased, et infot võiks küsida ilma eelküsimust esitamata. Jaatava vastuse järel läheb helistaja teema juurde. ${ }^{1}$

(3) ((kutsung))

V: Katrina kuuleb

H: .hhh tere Katrina. (.) Laura siin.

(.)

$\mathrm{V}:$ noo?

H: kuule, (.) `on sul natukene `aega minuga `rääkida.

V: no `räägi.

(.)

H: mul oleks `tarvis seda: (o.5) sinu selle koogiret`septi mille peal on `kookos`helbed.

Institutsionaalse dialoogi sissejuhatus on enamasti väga lühike, klient võib soovi või küsimuse esitada juba oma esimeses voorus. Voorud koosnevad sageli mitme sekventsi osadest (nt tutvustus + tervitus; tervitus + küsimus). Normiks on niisugune sissejuhatus, kus vastaja ennast tutvustab ning mõlemad osalejad tervitavad. Sõltuvalt vastaja tegevustest oma esimeses voorus on sissejuhatusel kaks tüüpilist varianti. 1. mudeli puhul (4) algab dialoog vastaja enesetutvustusega ning helistajat tervitatakse kohe samas voorus. Järgmises voorus tervitab helistaja vastu ning esitab oma soovi või küsimuse. Sissejuhatuse 2. mudelis (5) viiakse ühes voorus läbi vaid üks tegevus. (Rääbis 2006)

(4) 1. mudel

kutsung

V: tutvustus + tervitus

((kutsung))

H: tervitus + soov / küsimus

V: `info `telefon= 'Kersti=tere?

H: e tere, Pärnu õ `loodussõprade maja palun.

(5) 2. mudel

kutsung

((kutsung))

$\mathrm{V}$ : tutvustus

V: `Nordik=Reisid=`Piia=kuuleb.

$\mathrm{H}$ : tervitus

$\mathrm{H}$ : tere?

$\mathrm{V}$ : tervitus

$\mathrm{V}$ : tere

H: soov / küsimus

H: tahaks odavalt `Inglismaale sõita. 


\section{2. Õpikudialoogide ja autentsete vestluste sissejuhatuste võrdlus}

\subsubsection{Kutsung - vastus}

Numbri valimine on helistaja esimene tegevus, millega telefonikõne tegelikult algab. Õpikunäidetes kutsung ehk telefonihelin enamasti puudub: 56-st vestlusest oli ainult kahes telefonihelin ära toodud (vt näide 2). Paar näidet algavad helistamise kui tegevuse kirjeldusega (Kaarel helistab polikliinikusse (Leemets 2002: 122), Mari helistab Kuressaarde hotelli Valge Hobune (Pajusalu jt 1999: 194)).

Kuna õpikudialoogides kutsungit ei kasutata, ei ole kasutatud võimalust lähtuda dialoogi koostamisel kutsungi pikkusest. Telefonivestluses osalejatel on mingi ettekujutus sellest, mitu kutsungit enne vastamist on "paras”. Kui telefonile vastatakse liiga kiiresti või liiga aeglaselt, võib helistaja selle kohta küsimusi esitada (vt Schegloff 1986: 120). Suulise keele korpuses on näiteid pika vastamisaja kohta: 'magasid=vä; käisid 'kempsus=vä; 'mis sa nï kaua `tulid. (.) 'tegid midagi. Õppekirjanduse koostajatel oleks kutsungi arvessevõtmisega võimalik dialoogide loomulikkust suurendada ning reaalseid suhtlusolukordi tutvustada.

Telefonivestluses on normiks, et esimesena räägib vastaja (Schegloff 1968: 1076, Sacks 1992 [1972]: 542). See reegel ei kehti aga kõikides kultuurides, näiteks Ronald Wardhaugh (1992: 299) toob erandina välja jaapani telefonikõned, kus helistaja end kõigepealt tutvustab.

Kui normist kõrvale kaldutakse, näiteks võtab vastaja toru ega ütle midagi, esitab helistaja oma esimeses voorus verbaalse kutsungi (halloo). Eesti suulise keele korpuses on selle kohta ainult üks näide (6).

(6) ((on kuulda, et telefonitoru võetakse))

$\mathrm{H}$ : halloo

$\mathrm{V}: \mathrm{jah}$

(o.3)

$\mathrm{H}$ : tere.

$\mathrm{V}$ : ' tere $=$ Riina.

56-st õpikunäitest 27 algavad aga helistaja vooruga, telefonile vastamine on ära jäetud (7). See on iseloomulik eelkõige argivestluste näidetele.

(7) - Tere õhtust, kas Ott on kodus?

- Jaa, on küll. Kes küsib, palun?

- Tema sõber Tom.

- Tere, Tom! Ott teeb aias tööd, kohe kutsun. (Pesti, Ahi 1999: 132)

Neljal juhul pole selge, kumb on kumb osaleja. Näites (8) on kogu sissejuhatus ära jäetud.

(8) - Mis sa täna õhtul teed?

- Ma pean eesti keelt õppima.

- Õpi homme, lähme parem kinno! .. (Pesti, Ahi 1999: 50)

9. näite 1. reas sisalduvad nii vastaja kui helistaja tegevused, kuigi tegemist on helistaja vooruga (vastaja voor puudub). 
(9) A: Jaa. Hallo. Tere. Ülle siin. Kas Rein on kodus?

B: Ei ole.

A: Las ta helistab mulle.

B: Hästi. Ütlen edasi. (Mangus, Simmul 2009: 91)

Kui vastaja esimene voor on õpikunäites esitatud, on see loomulik, sarnanedes autentsete vestlustega. Viies näites tutvustab vastaja ennast (10), seitsmes mitte (11). Ühes õpikus kasutatakse vestluse alustamiseks tavaliselt üht moodust.

(10) - Hallo, Krista kuuleb.

- Tere päevast, Krista! Mina olen Anu. Mida sa praegu teed? ..

(Tomingas 2009: 91)

(11) A: Jaa, hallo!

B: Tere, kus sa oled? .. (Mangus, Simmul 2009: 91)

Institutsionaalse suhtluse näited õpikutes vastavad enamasti tegelikele suhtlussituatsioonidele. Dialoogi alustab vastaja (13 juhul 17-st), kes ütleb oma asutuse nime, kaheksas näites ka tervitab (12).

(12) - Eesti Kindlustus, tere päevast!

- Tere, siin räägib Toomas Meremaa Hansapangast. Kas ma saaksin rääkida hr Valgega? .. (Pesti, Ahi 1999: 122)

\subsubsection{Tervitamine}

Eesti suulise keele korpuse argivestlustes tervitab peaaegu alati esimesena helistaja (13). Vastaja tervitab esimeses voorus ainult mobiilikõnedes (14) või siis, kui ta on telefonile kutsutud - seega juhtudel, kui helistaja on juba enne vestlust identifitseeritud.

(13) ((kutsung))

$\mathrm{V}$ : jaa `Kaidi kuuleb.

(1.0)

H: tere õhtust.

(.)

$\mathrm{V}$ : tere=tere:

(o.8)

H: no kuidas `elad.

(14) ((kutsung))

$\mathrm{V}$ : no tere,

(o.3)

$\mathrm{H}:$ no `jõudu,

$\mathrm{V}$ : tarvis `tarvis.

H: kule räägi `mis pääval see kus kuhugi `minek on. 
Õpikunäidetes tervitab esimesena nii helistaja (15) kui ka vastaja (16).

(15) - Hallo, Mari kuuleb.

- Tere hommikust, Mari! Mina olen Mario.

- Tere, Mario! Kuidas käsi käib? .. (Tomingas 2009: 74)

(16) A: Hallo, tere!

B: Tere! Piret siin. Kas Urmas on kodus? .. (Mangus, Simmul 2009: 91)

Suulise keele korpuse institutsionaalsetes dialoogides algatab tervitustepaari ükskõik kumb osaleja. Ka õpikutes on näiteid nii vastaja kui helistaja algatatud tervituste kohta (17 ja 18).

(17) - Keelekeskus kuuleb. Tere päevast!

- Tere! Ma sooviksin õppida saksa keelt. Millal teil järgmine kursus algab? .. (Pesti, Ahi 1999: 132)

(18) ADMINISTRAATOR: Hotell Valge Hobune.

MARI: Tere. Ma sooviksin panna kinni neli kohta 23. ja 24. septembriks. Kas see on võimalik? .. (Pajusalu jt 1999: 194)

Näiteid on ka selle kohta, et tervitused ära jäetakse ning kohe teema juurde minnakse, seda nii argi- kui institutsionaalses suhtluses (19).

(19) INFO: Tallinna bussijaam.

ENE: Öelge palun, mis kell väljuvad hommikuti bussid Võrru? ..

(Pajusalu jt 1999: 126)

Tervitussõnadest domineerib õpikudialoogides tere (nagu ka suulise keele korpuses), tutvustatakse ka vormeleid tere päevast, tere õhtust, tere hommikust. Argiseid tervitusi, nt tšau ja tervitus, õpikutes ei kasutata.

\subsubsection{Identifitseerimine}

Kuna kutsung-vastus-sekvents paljudes õpikunäidetes puudub, pole sageli arusaadav, kuidas vestluses osalejate identifitseerimine toimub. Probleem on eelkõige argivestlustega. Institutsionaalsete dialoogide näited on üldiselt loomulikud: vastaja esimene voor on enamasti ära toodud ning see sisaldab alati tutvustust (vt näiteid $12,17,18,19)$.

Õpikutes on rohkesti näiteid selle kohta, et helistaja ei tunne vastajat ära. Peale ühe erandi puudub kõikides niisugustes näidetes vastaja esimene voor. Identifitseerimisprobleemi lahendamiseks kasutatakse küsimusi: Kas [nimi] kuuleb?, Kas see on [nimi] korter?, Kas see on [telefoninumber]?, Kas see oled sina, [nimi]? Mitteäratundmisele viitavad ka adressaadile endale esitatud küsimused Kas [nimi] on kodus?, Kas ma saan [nimi] rääkida?

Selliseid juhtumeid, kus kõnelejad teineteist hääle järgi ära ei tunne, tuleb ette ka reaalsetes suhtlussituatsioonides ja identifitseerimisprobleemi lahendamist tuleb 
kindlasti õpetada. Samas tuleks õppijate tähelepanu juhtida sellele, et niisugune probleem saab tekkida siis, kui vastaja ennast ei tutvusta. Näide (20) illustreerib identifitseerimisprobleemi (vastaja esimene voor puudub).

(20) - Tere päevast, kas see on Raamatu korter?

- Vabandage, ma ei saa aru! Palun rääkige veidi aeglasemalt!

- Kas see on 511898 ?

- Jaa, on küll.

- Kas see pole siis Raamatu korter?

- Ei, teil on vale number.

- Oi, vabandust. (Pesti, Ahi 1999: 20)

Üks näide (21) on õpikudialoogide hulgas ka niisugune, kus vastaja ei tunne helistajat ära. Kuna helistaja B ennast ei tutvusta, eeldab ta, et A on suuteline ta hääle järgi ära tundma. See viitab osalejate lähedastele suhetele. Helistaja küsimus kus sa oled? osutab mobiilikõnele, mille puhul vastaja identifitseerib vestluskaaslase tüüpiliselt juba enne vastamist personaalse telefonihelina järgi või ekraanil tema nime/numbrit nähes ning probleemi ei tohiks tekkida.

(21) A: Jaa, hallo!

B: Tere, kus sa oled?

A: Aga kes see räägib?

B: Mina, Lili!

A: Ah, sina.

B: Jah, kus sa oled? .. (Mangus, Simmul 2009: 91)

Helistaja tutvustuse kohta on õpikutes rohkesti näiteid, kuid ühes õpikus kasutatakse enamasti vaid üht vormelit: sïn [nimi] (Pesti, Ahi 1999), mina olen [nimi] (Tomingas 2009, Kitsnik, Kingisepp 2008, Pajusalu jt 1999), [nimi] sïn (Mangus, Simmul 2009). Veidi varieerumist on institutsionaalsetes dialoogides, kus on kasutatud ka vormeleid sïn räägib [nimi] ja teid tülitab [nimi].

Autentsetes vestlustes reageerib vastaja helistaja tutvustusele enamasti partikliga (jah, jaa, noh, nooh, noo, $\mathrm{mm}$ ). Sellega kinnitatakse äratundmist ning antakse voor helistajale tagasi. Näites (22) on tüüpiline identifitseerimissekvents: Kata `rïna sïn. / jaa?. Seejärel pakub helistaja teema.

(22) ((kutsung))

V: `Marju kuuleb.

$\mathrm{H}: \mathrm{mt}$ tere.

(o.3)

$\mathrm{V}$ : tere

H: Kata `riina siin. $=$

$\mathrm{V}:=\mathrm{jaa}$ ?

H: mt kas selle `suvise `reisi kohta `on nüd midagi konk`reetsemat.

Kui vastaja tutvustusele ei reageeri, järgneb tavaliselt paus, mis osutab sellele, et helistaja ootab reaktsiooni. Kui vooruvahetust ei toimu, võtab eelmine kõneleja vooru enda kätte tagasi. Näites (23) vestlevad sõbrad. Vastus jah ei olnud äratundmiseks piisav, Andres arvab, et telefonile vastas keegi teine. Pärast identifit- 
seerimisprobleemi lahendamist (kuulen jah?) tervitab ta uuesti ning ütleb oma nime. Veiko ei vasta tutvustusele ja vestluses tekib pikk paus. Seejärel hingab helistaja pikalt sisse ja esitab pärast veel üht lühikest pausi küsimuse no millega 'tegeled siis kah.

(23) ((kutsung))

$\mathrm{V}: \mathrm{jah}$

(0.5)

H: tere, kas `Veiko ka kodus on=vä.

(0.9)

$\mathrm{V}$ : kuulen jah?

(.)

H: mt=.hhh no tere:, (.) `Andres siinpool.

(o.8)

H: .hhhhh (o.3) no millega `tegeled siis kah.

Peaaegu kõikides õpikudialoogides jätkab helistaja vooru kohe tutvustuse järel, põimides ühte vooru tegevused, mis autentsetes dialoogides kuuluvad eri voorudesse. Näites (24) esitab Signe järjestikku tervituse ja tutvustuse ning alustab teemat.

(24) Gertrud: Jaa. Hallo. Tere!

Signe: Tere! Signe siin. Mida sa homme teed? ..

(Mangus, Simmul 2009: 126)

\subsubsection{Olukorda selgitavad küsimused}

Kuidas-läheb-küsimused ei ole eesti telefonivestlustes rutiinsed viisakusküsimused. Neid kasutatakse üsna harva (analüüsitud argikorpuse infovestlustest sisaldas kuidas-läheb-küsimusi 9\%, suhtehoidmisvestlustest 19\%) ning teatud tingimustel: teema esilekutsumiseks, eelküsimusena enne palve esitamist ning tegeliku küsimusena partneri olukorra, tervisliku seisundi või poolelioleva asjaajamise kohta (Rääbis 2009: 158-159).

Näide (25) on üles ehitatud vastavalt Ameerika mudelile: selles on vastastikused küsimused Kuidas käsi käib?, Ja kuidas sina elad?, mis saavad mõlemad lühikese neutraalse vastuse. Vormelit Kuidas käsi käib? pole suulise keele korpuses kordagi kasutatud, see tundub olevat pigem sõnastiku- ja õpikuvormel. Korpuses pole ühtki näidet ka selle kohta, et küsimusele järgneks tänamine. Niisuguses infovestluses nagu näites (25), mille eesmärk on kohtumise kokkuleppimine, kuidas-läheb-küsimusi pigem ei kasutata. Vestluskaaslase käekäigu järele pärimist ei tohiks õpikunäidetest mingil juhul välja jätta, küll aga tuleks selgitada, missugustel juhtudel eestlased niisuguseid küsimusi esitavad.

(25) - Hallo, Mari kuuleb.

- Tere hommikust, Mari! Mina olen Mario.

- Tere, Mario! Kuidas käsi käib?

- Tänan, hästi! Ja kuidas sina elad?

- Tänan, hästi ... Kas saame kokku?

- Hästi, saame kokku. Millal? Kas täna või homme? .. (Tomingas 2009: 74) 
Autentsete mobiilikõnede sissejuhatuses küsitakse väga sageli partneri asukohta, seda eelkõige mingi ühise tegevuse planeerimiseks (vt Arminen 2006). Eesti mobiilikõnesid ei ole eraldi uuritud, analüüsitud vähestes kõnedes esitati vastaja asukoha kohta küsimusi neljal juhul. Vestluskaaslase asukohta küsitakse ka kuues õpikunäites, mille eesmärk on kohtumise kokkuleppimine (26). Vaadeldavates õpikutes ei ole laua- ja mobiiltelefonivestlused selgelt eristatud, õppijad peavad sellest dialoogi sisu järgi ise aru saama.

(26) - Hallo, Mari kuuleb.

- Mari, kus sa oled?

- Ema? Ma olen Raekoja platsil. Joon kohvi. Mario joob teed. Aga sina?

- Mina? Mina olen Vabaduse väljakul... Kus me kokku saame?

- Vabandust, ema! Me oleme Raekoja platsil, Raekoja kohvikus. Palun tule Raekoja platsile.

- Ma tulen Raekoja platsile. Nägemiseni! (Tomingas 2009: 79)

Kahes õpikunäites küsib helistaja, kas vestluskaaslane saab rääkida. Niisugune küsimus näitab partneriga arvestamist ning selle õpetamine on igati asjakohane (27).

(27) A: Tere, kas ma saan Aleksandriga rääkida?

B: Jah, ma kuulen.

A: Larissa siin. Kas te saate praegu rääkida?

B: Saan küll.

A: Asi on selles, et ma ei saa täna tulla. Ma pean täna Tartusse sõitma. . (Mangus, Simmul 2009: 129)

Mõnes näites teatab vastaja, et aeg pole kõneluseks sobiv, ning palub uuesti helistada (28) või lubab ise tagasi helistada.

(28) A: Hallo. Tere!

B: Tere!

A: Kuule, ma tahtsin küsida, et...

B: Kas sa saad mulle õhtul tagasi helistada, ma ei saa praegu rääkida?!

A: Teeme nii. Head aega! (Mangus, Simmul 2009: 129)

Näites (29) küsib helistaja Mida sa praegu teed? Nagu autentsetes vestlusteski (30), valmistab see küsimus ette kohtumisettepanekut.

(29) - Hallo, Krista kuuleb.

- Tere päevast, Krista! Mina olen Anu. Mida sa praegu teed?

- Praegu teen kohvi. Pärast teen tööd. Aga sina?

- Mina teen praegu tööd.

- Aga pärast tööd? Kas sa pärast tööd puhkad?

- Puhkan! Saame pärast tööd kokku. Aga kus?

- Minu kodus. Sõidame Pärnusse puhkama! Mu hea sõber puhkab laupäeviti ja pühapäeviti Pärnus.

- Hästi! Tulen õhtul pärast tööd. Sõidame Pärnusse! Nägemiseni!

- Nägemiseni! (Tomingas 2009: 91) 
(30) V2: hallo

H: .hhhhhhhhh `mina siin. ((koer haugatab))

(0.5)

V2: noh

$\mathrm{H}$ : .hhhh (o.3) mis `teed. $=\mathrm{h}$

V2: mina (0.5) ee ma kirjutan praegu `Merjele neid (o.3) mis me oleme 'tunnis teind.

H: .ma=.tahtsin=muidu `õue kutsuda sind.

V2: ma võin `pärast`poole tulla.

\subsubsection{Sissejuhatuse tervikstruktuur}

Vaadeldavates õpikutes on kokku 30 argivestlust ja 17 institutsionaalset dialoogi. Ainult 12 argivestluses ja 13 institutsionaalses dialoogis on sissejuhatus tervikuna ära toodud. Ülejäänud vestlustes puudub vastaja esimene voor või algab näide kohe teemaga.

Õpikudialoogide voorud on mõnikord üleliia pikad ning ühte vooru on liidetud tegelikes vestlustes eri sekventsidesse kuuluvad tegevused. Näite (31) esimeses voorus on kokku pandud tervitamine, partneri äratundmise väljendamine (vastaja avavoor puudub, vestlus algab helistaja vooruga), enda tutvustamine ja kaks küsimust. Mitmeosalised voorud on ka autentsetes vestlustes tavalised, kuid üle kahe komponendi harilikult järjestikku ei esitata. Ka suulise keele korpuse näites (32) alustab helistaja vooru tervitusega, kinnitab identifitseerimist partneri nime nimetades ning ütleb oma nime. Kuid seejärel vastab Elo tervitusele ning Reet läheb teema juurde alles järgmises voorus.

(31) - Tere, Maret! Mina olen Anna Maria. Kus sa oled? Kas sa oled Eestis?

- Tere, Anna Maria! Ei, ma ei ole Eestis, ma olen Rootsis.

- Rootsis? Väga tore! (Tomingas 2009: 33)

(32) ((kutsung))

V: `Elo kuuleb?

$\mathrm{H}: \mathrm{mt}=. \mathrm{hh}$ tere `Elo, `Reet olen=h.

$\mathrm{V}$ : ‘tervist.

(.)

H: `n:oh? (.) kui `kaua sa veel `püsid `Tartus.

Lühemate voorudega näited on loomulikumad. Näidet (33) alustab vastaja partikliga jaa. Helistaja tervitab ning küsib vestluskaaslase asukohta. Saanud vastuse, teeb ta ettepaneku kohtuda. Nagu autentsetes vestlusteski pakub õpikunäidetes vestluse esimese teema tavaliselt helistaja.

(33) A: Jaa!

B: Tere! Kus sa oled praegu?

A: Lasnamäel.

B: Saame kokku! .. (Mangus, Simmul 2009: 91) 
Autentsete vestlustega sarnanevad ka need näited, milles telefonile ei vasta adressaat (vrd (34) ja (35)). Sissejuhatus on sel juhul väga lühike. Helistaja alustab oma esimest vooru tervitusega (ühes näites järgneb ka tutvustus) ning küsib kohe samas voorus adressaati.

(34) Naine: Hallo!

Mees: Tere! Palun Üllet!

Naine: Jah, ma kohe kutsun. (Kitsnik, Kingisepp 2008: 145)

(35) ((kutsung))

V1: hallo

$\mathrm{H}$ : tere palun `Maarikat.

V1: jah

(1.1)

V1: MAARIKA? ((hõikab))

Institutsionaalsete telefonidialoogide algused on õpikutes loomulikud, sarnanedes suulise keele korpuse dialoogidega. Vastaja esimene voor sisaldab alati tutvustust, millele võidakse lisada ka tervitus. Helistaja alustab vooru tervitusega ning esitab samas voorus soovi või küsimuse.

Näited (36) ja (37) illustreerivad teema ja struktuuri poolest sarnaseid institutsionaalseid õpiku- ja korpusedialooge.

(36) A: Tere! Firma Takso kuuleb.

B: Tere õhtust! Soovin taksot tellida.

A: Teie aadress, palun!

B: Koorti 10-40. .. (Mangus, Simmul 2009: 114)

(37) ((kutsung))

$\mathrm{V}$ : `Maria $=$ Takso tere.

(.)

H: tere. (o.5) sooviks `taksot.

$\mathrm{V}$ : ja: 'kuhu.

(o.8)

$\mathrm{H}$ : `Jalaka puiestee kuus `teist.

\section{Kokkuvõte}

Õpikudialooge eristab autentsetest dialoogidest lisaks kutsungi puudumisele kõige enam vastaja esimese vooru sagedane puudumine, seda eriti argivestlustes. Institutsionaalsed dialoogid õpikutes vastavad enamasti reaalsetele suhtlussituatsioonidele ning neis on ka vastaja avavoor tavaliselt olemas, mistõttu ei teki neis erinevalt argivestlustest ka probleeme vastaja identifitseerimisega. Õpikuvestluste autentsust vähendab mõnikord ka voorude ülemäärane pikkus ning eri sekventsidesse kuuluvate tegevuste ühte vooru põimimine.

Enamikus õpikute argivestluse näidetes on helistaja eesmärk kutse esitamine või kokkusaamise kavandamine. Vaadeldud õpikutes puuduvad suhtehoidmis- 
vestluse näited, kus helistamise põhjus ongi lihtsalt sotsiaalsete suhete hoidmine, igapäevastest asjadest lobisemine (nt lahus elavate pereliikmete vestlused), mis tegelikus elus on väga tavalised.

Selgelt tuleb esile õpikuvestluste metoodiline eesmärk - pakkuda õppijatele vajalikke keelelisi vahendeid suhtlusprobleemide lahendamiseks ja enda soovide arusaadavaks edastamiseks, seejuures on telefonivestlustel sageli äratuntavalt ka mõne grammatika- või sõnavarateema õpetamise funktsioon. Õpikute autorid peavad vajalikuks valmistada õppijaid ette vestluse ebaõnnestumiseks - õpikutes on silmatorkavalt palju näiteid olukordadest, kus on valitud vale number, vastajat või helistajat ei tunta ära, adressaati pole kodus või ei saa ta parajasti rääkida jne.

Autentsetes telefonidialoogides ei tooda esimest teemat vestlusse suvalises kohas. Ankrupositsioonile jõutakse samm-sammult, suhtlejate ühise töö tulemusena. Iga konkreetse telefonivestluse sissejuhatuse ülesehitus sõltub osalejate suhetest, kontaktide sagedusest, vestlustüübist, helistamise põhjusest jms ning alati ka partneri eelnevast tegevusest. Kõiki eripärasid pole mõeldav õpikutes tutvustada. Kui aga õpikudialoogis sissejuhatavad sekventsid üldse puuduvad ja telefonivestlus algab kohe teemaga, ei saa õppija teada, kuidas teemani jõuti. Kui õpikus on mingi teema esitamiseks valitud telefonivestlus, on kasulik esitada terviklik dialoog, see suurendab õpikuteksti autentsust ning tutvustab õppijatele eestikeelses vestluskultuuris kasutatavaid suhtluskonventsioone.

Käsitletud õpikud on ilmunud kümne aasta jooksul ning tehnika areng paistab välja ka neis esitatud telefonivestlustest: 1999. a ilmunud "E nagu Eestis" on ainult lauatelefonikõned, 2008. ja 2009. a ilmunud õpikutes on juba märkimisväärne hulk mobiiltelefonivestlusi. Telefonikõne alguse struktuur, nii vastamine, tervitamine kui ka identifitseerimine, võib mobiilikõne puhul olla lauatelefonist üsna erinev ning see nõuab ka õppematerjalide koostajatelt teistsugust lähenemist.

Eesti keele õpikute telefonidialoogid järgivad üldiselt kirjakeele normi ja suulisele keelekasutusele omaseid sõnavaralisi ja häälikulisi iseärasusi (nt üneemid, partiklid, sõnakordused jne) neis ei kohta. Algajatele mõeldud õppevahendites on korrektse keelekasutuse taotlemine asjakohane. Suulise keele eripära tutvustamine eeldab õppijatelt juba teatud tasemel keeleoskust ja võimet eri registreid eristada ning sellega tegeldakse üldjuhul edasijõudnud õppijate keeletundides. Samas on ka algtasemel õppijatele võimalik tutvustada autentsete telefonivestluste ülesehitust, tegemata selleks erilisi grammatilisi või sõnavaralisi jõupingutusi. Praeguseks on olemas juba piisavalt uurimistulemusi eestikeelsete telefonivestluste struktuuri iseärasuste kohta, mida tulevastel õppematerjalide koostajatel oleks võimalik ära kasutada ning seeläbi õpikudialoogide autentsust suurendada.

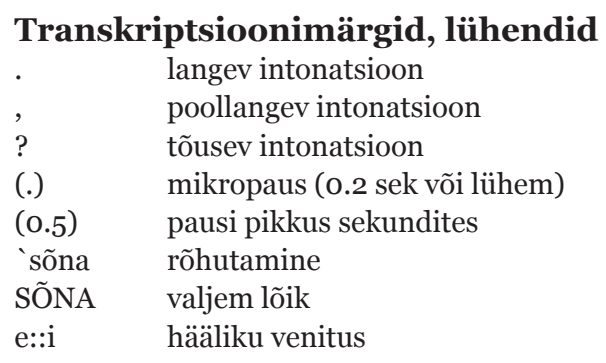




$\begin{array}{ll}. h h & \text { sissehingamine } \\ \text {.jaa } & \text { sisse hingates lausutud sõna } \\ \mathrm{hh} & \text { väljahingamine } \\ \mathrm{mt} & \text { matsutamine } \\ = & \text { kahe iseseisva üksuse kokkuhääldamine } \\ ((\mathrm{)}) & \text { transkribeerija kommentaar } \\ \mathrm{H} & \text { helistaja } \\ \mathrm{V}, \mathrm{V1}, \mathrm{V} 2 & \text { vastaja }\end{array}$

\section{Viidatud kirjandus}

Arminen, Ilkka 2005. Sequential order and sequence structure - the case of incommensurable studies on mobile phone calls. - Discourse Studies, 7, 6, 649-662. doi:10.1177/1461445605055421

Arminen, Ilkka 2006. Social functions of location in mobile telephony. - Personal and Ubiquitous Computing, 10, 5, 319-323. doi:10.1007/s00779-005-0052-5

Arminen, Ilkka; Leinonen, Minna 2006. Mobile phone call openings - tailoring answers to personalized summons. - Discourse Studies, 8, 3, 339-368. doi:10.1177/1461445606061791

Carter, Ronald 1998. Orders of reality: CANCODE, communication, and culture. - ELT Journal, 52, 1, 43-56. doi:10.1093/elt/52.1.43

Coronel-Molina, Serafin M. 1998. Openings and closings in telephone conversations between native Spanish speakers. - Working Papers in Educational Linguistics, 14, 1, 49-68.

Crossley, Scott A.; Louwerse, Max M.; McCarthy, Philip M.; McNamara, Danielle S. 2007. A linguistic analysis of simplified and authentic texts. - The Modern Language Journal, 91, 1, 15-30. doi:10.1111/j.1540-4781.2007.00507.x

Gilmore, Alex 2004. A comparison of textbook and authentic interactions. - ELT Journal, 58, 4, 363-374. doi:10.1093/elt/58.4.363

Granena, Gisela 2008. Elaboration and simplification in Spanish discourse. - International Review of Applied Linguistics in Language Teaching, 46, 2, 137-166. doi:10.1515/ IRAL.2008.006

Guariento, William; Morley, John 2001. Text and task authenticity in the EFL classroom. ELT Journal, 55, 4, 347-353. doi:10.1093/elt/55.4.347

Hakulinen, Auli 1992. Rutiinien syntaksia. - Heikki Paunonen, Matti Suojanen, Kari Nahkola (Toim.). Variaatioita. Tampereen yliopiston suomen kielen ja yleisen kielitieteen laitoksen juhlakirja. Opera Fennistica \& Linguistica, 4. Tampere: Tampereen yliopiston suomen kielen ja yleisen kielitieteen laitos, 27-44.

Hennoste, Tiit 2000. Suulise eesti keele uurimine: transkriptsioon, taust ja korpus. - Keel ja Kirjandus, 2, 91-106.

Hennoste, Tiit 2003. Suulise eesti keele uurimine: korpus. - Keel ja Kirjandus, 7, 481500 .

Hutchby, Ian; Barnett, Simone 2005. Aspects of the sequential organisation of mobile phone conversation. - Discourse Studies, 7, 2, 147-171. doi:10.1177/1461445605050364

Lee, Seung-Hee 2006. Second summonings in Korean telephone conversation openings. Language in Society, 35, 2, 261-283. doi:10.1017/So047404506060118

Liefländer-Koistinen, Luise; Neuendorff, Dagmar 1989. Making phone-calls in German and Finnish: a discourse analytic comparison between actual calls and those presented in elementary textbooks for foreign learners. - Jussi Niemi (Ed.). Papers from the Eleventh Scandinavian Conference of Linguistics, Vol. 2. Joensuu: University of Joensuu, Faculty of Arts, 368-384.

van Lier, Leo 1996. Interaction in the Language Curriculum: Awareness, Autonomy and Authenticity. London, New York: Longman. 
Lindström, Anna 1994. Identification and recognition in Swedish telephone conversation openings. - Language in Society, 23, 2, 231-252. doi:10.1017/S004740450001784X

Nissilä, Leena; Martin, Maisa; Vaarala, Heidi; Kuukka, Ilona 2006. Saako olla suomea? Opas suomi toisena kielenä -opetukseen. Saarijärvi: Opetushallitus.

Pavlidou, Theodossia-Soula 1994. Contrasting German-Greek politeness and the consequences. - Journal of Pragmatics, 21, 5, 487-511. doi:10.1016/0378-2166(94)90026-4

Rääbis, Andriela 2006. Infodialoogi algusrituaalid. - M. Koit, R. Pajusalu, H. Õim (Toim.). Keel ja arvuti. Tartu Ülikooli üldkeeleteaduse õppetooli toimetised, 6. Tartu: Tartu Ülikooli Kirjastus, 143-155.

Rääbis, Andriela 2009. Eesti telefonivestluste sissejuhatus: struktuur ja suhtlusfunktsioonid. Dissertationes linguisticae Universitatis Tartuensis, 13. Tartu: Tartu Ülikooli Kirjastus.

Sacks, Harvey 1992 [1964-1972]. Lectures on Conversation. Gail Jefferson (Ed.). Cambridge, Oxford: Blackwell.

Sacks, Harvey; Schegloff, Emanuel A.; Jefferson, Gail 1974. A simplest systematics for the organization of turn-taking for conversation. - Language, 50, 4, 696-735. doi:10.2307/412243

Schegloff, Emanuel A. 1968. Sequencing in conversational openings. - American Anthropologist, 70, 1075-1095. doi:10.1525/aa.1968.70.6.02a00030

Schegloff, Emanuel A. 1986. The routine as achievement. - Human Studies, 9, 111-152. doi:10.1007/BFo0148124

Schegloff, Emanuel A. 2007. Sequence Organization in Interaction. A Primer in Conversation Analysis, Vol. 1. New York: Cambridge University Press. doi:10.1017/ CBO9780511791208

Schegloff, Emanuel A.; Sacks, Harvey 1973. Opening up closings. - Semiotica, 8, 289-327.

Sifianou, Maria 2002. On the telephone again! Telephone conversation openings in Greek. K. K. Luke, T.-S. Pavlidou (Eds.). Telephone Calls. Unity and Diversity in Conversational Structure across Languages and Cultures. Pragmatics \& Beyond New Series, 101. Amsterdam, Philadelphia: John Benjamins, 49-85. doi:10.1515/semi.1973.8.4.289

Sun, Hao 2004. Opening moves in informal Chinese telephone conversations. - Journal of Pragmatics, 36, 8, 1429-1465. doi:10.1016/j.pragma.2004.01.007

Taleghani-Nikazm, Carmen 2002. A conversation analytical study of telephone conversation openings between native and nonnative speakers. - Journal of Pragmatics, 34, 12, 1807-1832. doi:10.1016/So378-2166(02)00049-8

Tanner, Johanna 2008. S2-oppikirjojen dialogien tarkastelua. - Johanna Tanner, Marja Kokkonen (Toim.). Suomenopetus, kielitaito ja tutkimus. Kakkoskieli, 6. Helsinki: Helsingin yliopiston suomen kielen ja kirjallisuuden laitos, 163-189.

Wardhaugh, Ronald 1992. An Introduction to Sociolinguistics. Cambridge, Oxford: Blackwell.

Wong, Jean 2002. "Applying” conversation analysis in applied linguistics: Evaluating dialogue in English as a second language textbooks. - International Review of Applied Linguistics in Language Teaching, 40, 1, 37-60. doi:10.1515/iral.2002.003

\section{Materjali allikad}

Kitsnik, Mare; Kingisepp, Leelo 2008. Teach Yourself Estonian. London: Teach Yourself.

Leemets, Helle 2002. Sammhaaval. Eesti keele õpik alg- ja kesktasemele. Tallinn: Eesti Keele Sihtasutus.

Mangus, Inga; Simmul, Merge 2009. Tere! Eesti keele õpik algajatele o-A1. Eesti Ekspressi Kirjastuse AS. 
Pajusalu, Renate; Hietaharju, Merja; Taro, Viive; Yallop, Kai 1999. Keelesild. Viron kielen oppikirja. Helsinki: Otava.

Pesti, Mall; Ahi, Helve 1999. E nagu Eesti. Tallinn: TEA.

Tomingas, Silva 2009. Saame tuttavaks! Viron kielen alkeet. Tallinn: TEA.

Raili Pooli (Tartu Ülikool) uurimisvaldkond on eesti keele kui teise keele õpetamine ja omandamine. raili.pool@ut.ee

Andriela Rääbise (Tartu Ülikool) uurimisvaldkonnad on suuline kõne, telefonisuhtlus, infodialoogide struktuur.

andriela.raabis@ut.ee 


\title{
TELEPHONE CONVERSATIONS IN ESTONIAN AS A SECOND LANGUAGE TEXTBOOKS: FUNCTIONS OF DIALOGUES AND STRUCTURE OF OPENINGS
}

\author{
Raili Pool, Andriela Rääbis \\ University of Tartu
}

\begin{abstract}
This article examines the functions and structure of the telephone conversations found in the textbooks of Estonian as a foreign language intended for adult beginner learners; the focus is on the openings of the conversations. The collected data includes 56 telephone dialogues taken from six Estonian textbooks published during 1999 to 2009 (Pajusalu jt 1999, Pesti, Ahi 1999, Leemets 2002, Kitsnik, Kingisepp 2008, Mangus, Simmul 2009, Tomingas 2009), the comparative data includes 131 everyday and 577 institutional telephone conversations taken from the Tartu University Corpus of Spoken Language (http://www.cl.ut.ee/suuline/). Based on the comparison of the two datasets, it can be claimed that, in addition to the lack of summons, the most important thing that differentiates the textbook dialogues from the corpus dialogues is the frequent lack of the answerer`s first turn; this is especially the case with everyday conversations. Moreover, it is not always clear how the participants in everyday textbook conversations come to mutual recognition. The results of our current research indicate the following conclusions: institutional textbook dialogues generally correspond to real communicative situations. Sometimes, however, the authenticity of textbook conversations is lessened by the excessive length of the turns and the integration of actions belonging to different sequences into one and the same turn. The didactic aim of the textbook dialogues is evident - to offer language learners necessary linguistic means to solve different communication problems. In addition to the pragmatic functions of the telephone conversations, these telephone conversations also fulfil certain grammar or vocabulary teaching functions.
\end{abstract}

Keywords: second language teaching, conversation analysis, opening of telephone conversations, authenticity, Estonian 